\title{
Activity of key enzymes involved in glucose and triglyceride catabolism during bovine oocyte maturation in vitro
}

\author{
P. Cetica, L. Pintos, G. Dalvit and M. Beconi* \\ Area of Biochemistry, School of Veterinary Sciences, University of Buenos Aires, \\ Chorroarín 280, (C1427CWO) Buenos Aires, Argentina
}

Little is known about the metabolic profile of cumulusoocyte complexes (COCs) during maturation. The aim of this study was to determine the differential participation of enzymatic activity in cumulus cells and the oocyte during in vitro maturation of bovine oocytes, by measuring the activity of key enzymes involved in the regulation of glycolysis (phosphofructokinase), the pentose phosphate pathway (glucose-6-phosphate dehydrogenase) and lipolysis (lipase). COCs were matured in medium 199 plus $10 \%$ $(\mathrm{v} / \mathrm{v})$ steer serum for $22-24 \mathrm{~h}$ at $39^{\circ} \mathrm{C}$ in $5 \% \mathrm{CO}_{2}: 95 \%$ humidified air. Phosphofructokinase, glucose-6-phosphate dehydrogenase and lipase activities were measured in immature and in vitro matured COCs, denuded oocytes and cumulus cells, respectively. Phosphofructokinase and glucose-6-phosphate dehydrogenase activities (enzymatic units) remained constant during in vitro maturation of COCs, but there was a significant decrease in lipase activity (units) $(P<0.05)$, as activity in cumulus cells decreased significantly $(P<0.05)$. For the three enzymes studied, enzyme activity (units) remained unchanged in the oocyte during in vitro maturation. Specific activity increased in the oocyte $(P<0.05)$ and decreased in cumulus cells as a result of maturation $(P<0.05)$. In cumulus cells, phosphofructokinase was the most abundant of the three enzymes followed by glucose-6-phosphate dehydrogenase and then lipase $(P<0.05)$, whereas in the denuded oocyte this order was reversed $(P<0.05)$. Thus, the metabolism of cumulus cells is adapted to control the flow of metabolites toward the oocyte, which maintains its enzymatic activity even when dissociated from cumulus cells during maturation. The high activity of phosphofructokinase in cumulus cells indicates that glucose is metabolized mainly via the glycolytic pathway in these cells. The greater relative activity of glucose-6-phosphate dehydrogenase recorded in the oocyte indicates that glucose uptake could be directed mainly toward the pentose phosphate pathway. The marked lipolytic activity concentrated in the oocyte indicates an active participation in lipid catabolism during maturation.

\section{Introduction}

The procedure for producing bovine embryos in vitro is unsatisfactory, in part, because little information is available regarding essential culture conditions for the oocyte for in vitro maturation. The cytoplasm of the oocyte provides the appropriate metabolic requirements for the production of energy necessary for cellular function during maturation, fertilization and early embryo development. The physiology of the zygote and the embryo in the early developmental stages is considered as an extension of the physiology of the oocyte (Gardner, 1998).

Oocyte maturation depends mainly on the presence of surrounding cumulus cells, which perform nutritive and regulatory functions during this process (Sutovsky et al., 1993; Cetica et al., 1999a). When cumulus-oocyte complexes (COCs) maintain prolonged oocyte-corona coupling

*Correspondence: Area de Química Biológica, Facultad de Ciencias Veterinarias, Universidad de Buenos Aires, Chorroarín 280, C1427CWO Buenos Aires, Argentina

Email: beconi@fvet.uba.ar during maturation, a greater proportion of oocytes mature, highlighting the role of cumulus cells in this process (de Loos et al., 1991; Laurincik et al., 1992).

In rodents, it has been proposed that cumulus cells metabolize glucose producing glycolytic metabolites used by the oocyte for growth and maturation (Leese and Barton, 1984; Buccione et al., 1990). Under the action of $\mathrm{LH}$, there is an increase in glucose uptake by bovine COCs, possibly because of enhanced activities of the glycolytic and Krebs' cycle (Zuelke and Brackett, 1992). In glucose-rich media, a higher percentage of maturation was observed in bovine COCs in comparison with denuded oocytes. When these media were supplemented with pyruvate or lactate plus $\mathrm{NAD}$, the percentage of COCs that matured remained unchanged, but the number of denuded oocytes that matured was greater, indicating that the gamete used substrates derived from glucose oxidation (Susko-Parrish et al., 1992; Cetica et al., 1999b). The lack of glucose uptake by the bovine oocyte indicates activities of glycolysis and the pentose phosphate pathway are low in the gamete during maturation (Rieger and Loskutoff, 1994).

There is little information on the use of lipids as oxidative 
substrates for bovine oocytes during maturation. Unlike human, equine and rodent oocytes, bovine oocytes contain a large number of lipid droplets, which are associated with the endoplasmic reticulum and mitochondria, so that their redistribution during maturation may be related to possible metabolic changes (Kruip et al., 1983).

Metabolic studies in vitro show that substrate uptake by the oocyte fails to reflect physiological concentrations prevailing during in vivo maturation, which may lead to erroneous interpretations (Barnett and Bavister, 1996); however, there are no data indicating that the abundance of enzymes in the oocyte is modified by substrate concentrations in culture media. Thus, the activity of key enzymes responsible for regulating the rate of a metabolic pathway may be a useful approach to determine the participation of a given metabolic route in the cells studied. Phosphofructokinase is the main enzyme regulating glycolysis, and performs a key function in controlling the pathway rate (Schirmer and Evans, 1990). The pentose phosphate pathway is an alternative pathway for glucose oxidation and is regulated by glucose-6-phosphate dehydrogenase $(\mathrm{G} 6 \mathrm{PDH})$, the activity of which is dependent on NADPH: NADP ratio (Wood, 1986; Clarenburg, 1992a).

There are few studies on key enzymes involved in glucose oxidation pathways during maturation of mammalian oocytes and their findings differ among species. In mouse oocytes, there is no variation in lactate dehydrogenase and G6PDH activities as a result of maturation (Mangia and Epstein, 1975). In rats, an increase in hexokinase, phosphofructokinase and malate dehydrogenase activities were recorded, with a decrease in G6PDH and 6-phosphogluconate dehydrogenase activities, but without changes in lactate dehydrogenase activity during in vitro maturation (Tsutsumi et al., 1992). In COCs and bovine oocytes, lactate dehydrogenase activities remained constant during maturation, displaying a differential distribution of isoenzymes between oocytes and cumulus cells (Cetica et al., 1999b).

Lipases are mostly non-specific enzymes that hydrolyse triglycerides as the first step in their catabolism and the resultant fatty acids may be oxidized in mitochondria. Enzyme activity may be regulated by induction of synthesis or by covalent modification (Khoo and Steinberg, 1981; Clarenburg, 1992b). In the tobacco hornworm (Manduca sexta), lipoprotein lipase activity was associated with ovarian follicles, which appear to provide lipid to the oocyte (Van Antwerpen et al., 1998). Ovarian granulosa cells in hens exert lipase activity, and presumably degrade triglycerides to provide the oocyte with fatty acids (Benson et al., 1975).

There are few available studies that demonstrate at the biochemical level the relative importance of metabolic pathways in bovine COCs during the maturation process in vitro. Knowledge of key enzyme activities of the catabolic pathway will contribute to elucidate the metabolic profile of both cumulus cells and of the oocyte in maturation. The aim of the present study was to investigate the differential participation of enzymatic activity in cumulus cells and in the oocyte during in vitro maturation of bovine oocytes, by studying the activity of key enzymes involved in the regulation of glycolysis (phosphofructokinase), the pentose phosphate pathway (G6PDH) and lipolysis (lipase).

\section{Materials and Methods}

\section{Materials}

All chemicals used were purchased from Sigma Chemical Company (St Louis, MO), except for medium 199 (Earle's salts, L-glutamine, $2.2 \mathrm{mg}$ sodium bicarbonate $\mathrm{I}^{-1}$ ), which was purchased from GIBCO BRL (Grand Island, NY).

\section{Recovery and classification of COCs}

Bovine ovaries were obtained from an abattoir within 30 min of slaughter and kept warm $\left(30^{\circ} \mathrm{C}\right)$ during the $2 \mathrm{~h}$ journey to the laboratory. Ovaries were washed in physiological saline containing 100000 iu penicillin $\mathrm{I}^{-1}$ and $100 \mathrm{mg}$ streptomycin $\mathrm{I}^{-1}$. COCs were recovered by aspiration of antral follicles (2-5 mm in diameter) and classified according to the morphology of cumulus cells under a stereomicroscope. Only oocytes that were completely surrounded by compact and thick cumulus were used.

\section{In vitro maturation of oocytes}

COCs were cultured in medium 199 supplemented with $10 \%(\mathrm{v} / \mathrm{v})$ steer serum and $50 \mathrm{mg}$ gentamicine sulphate $\mathrm{I}^{-1}$ under paraffin oil at $39^{\circ} \mathrm{C}$ for $22-24 \mathrm{~h}$ in a atmosphere of $5 \% \mathrm{CO}_{2}$ with humidified air. Meiotic maturation was evaluated using $10 \%$ of the samples. Oocytes were placed in a hypotonic medium of $10 \mathrm{~g}$ sodium citrate $\mathrm{I}^{-1}$ at $37^{\circ} \mathrm{C}$ for $15 \mathrm{~min}$, fixed on a slide with acetic acid-alcohol (Tarkowski, 1966), stained with 5\% (v/v) Giemsa for $15 \mathrm{~min}$ and observed under a light microscope at $\times 100$ and $\times 400$ magnifications. Oocytes were considered mature when metaphase II chromosome configuration was present.

\section{Denuded oocytes}

Immature or matured oocytes were denuded by vortex agitation in sterile physiological saline for $1 \mathrm{~min}$ and then collected with a pipette to separate the oocytes from cumulus cells. Denuded oocytes were washed twice in the same medium to eliminate residual cumulus cells.

\section{Preparation of enzymatic extract}

Immature or in vitro matured COCs and denuded oocytes were suspended in distilled water, frozen-thawed twice, centrifuged at $1000 \mathrm{~g}$ for $20 \mathrm{~min}$ at $4^{\circ} \mathrm{C}$ and enzyme activities determined in the supernatants. Residual cumulus cells suspended in physiological saline were processed in the same way.

Extracts were prepared so that the final amount of each enzyme ensured linear behaviour during activity measurement, thus enabling absorbance per min variation to be calculated. 


\section{Determination of phosphofructokinase activity}

Phosphofructokinase activity was determined in extracts of immature or in vitro matured COCs $(n=60)$ and from denuded oocytes $(n=250)$. Activity was measured in a spectrophotometer at $340 \mathrm{~nm}$ for $2.5 \mathrm{~min}$ at $37^{\circ} \mathrm{C}$ in 95 mmol Tris- $\mathrm{HCl}$ buffer $\mathrm{I}^{-1}$, $\mathrm{pH} 8.2,100 \mathrm{mmol} \mathrm{MgCl}_{2} \mathrm{I}^{-1}$, $2 \mathrm{mmol} \mathrm{NADH} \mathrm{I}{ }^{-1}, 100 \mathrm{mmol} \mathrm{NH}_{4} \mathrm{Cl} \mathrm{I}^{-1}, 20 \mathrm{mmol}$ fructose6 -phosphate $\mathrm{I}^{-1}, 1 \mathrm{mmol}^{\mathrm{ATP}} \mathrm{I}^{-1}$ and $1 \mathrm{mmol} \mathrm{AMP}^{-1}$ in the presence of (1) $70 \mathrm{mg}$ aldolase $\mathrm{I}^{-1}$, (2) $3 \mathrm{mg}$ phosphotriose isomerase $\mathrm{I}^{-1}$ or (3) $30 \mathrm{mg}$ glycerol-3-phosphate dehydrogenase $\left.\right|^{-1}$ (Kotlarz and Buc, 1982). An enzymatic unit of phosphofructokinase is defined as the quantity of enzyme that catalyses the formation of $1 \mu \mathrm{mol}$ fructose-1,6biphosphate $\min ^{-1}=$ the oxidation of $2 \mu \mathrm{mol} \mathrm{NADH} \mathrm{min}^{-1}$.

\section{PFK}

Fructose-6-phosphate + ATP $\rightarrow$ fructose-1-6-biphosphate + ADP

(1) Fructose-1-6-biphosphate $\leftrightarrow$ glyceraldehyde-3phosphate + dihydroxyacetone phosphate

(2) Glyceraldehyde-3-phosphate $\leftrightarrow$ dihydroxyacetone phosphate

(3) 2 Dihydroxyacetone phosphate $+2 \mathrm{NADH} \leftrightarrow 2$ glycerol-3-phosphate + 2NAD

\section{Determination of G6PDH activity}

G6PDH activity was determined in extracts of immature or in vitro matured COCs $(n=35)$ and from denuded oocytes $(n=100)$. Activity was measured in a spectrophotometer at $340 \mathrm{~nm}$ for $10 \mathrm{~min}$ at $30^{\circ} \mathrm{C}$ in $40 \mathrm{mmol}$ glycine buffer $\mathrm{I}^{-1}$, $\mathrm{pH} 7.5,12.5 \mathrm{mmol} \mathrm{MgCl}_{2} \mathrm{I}^{-1}, 1.5 \mathrm{mmol}$ NADP $\mathrm{I}^{-1}, 12.0 \mathrm{mmol}$ maleimide $\mathrm{I}^{-1}$ and $1.05 \mathrm{mmol}$ glucose-6phosphate ${ }^{-1}$ (Kornberg and Horecker, 1955; Lohr and Waller, 1974). An enzymatic unit of G6PDH is defined as the quantity of enzyme that catalyses the reduction of $1 \mu \mathrm{mol}$ NADP $\mathrm{min}^{-1}$.

\section{G6PDH}

Glucose-6-phosphate + NADP $\rightarrow$ 6-phosphogluconolactone $+\mathrm{NADPH}$

\section{Determination of lipase activity}

Lipase activity was determined in extracts of immature or in vitro matured COCs $(n=40)$ and from denuded oocytes $(n=100)$. Activity was measured in a spectrophotometer at $550 \mathrm{~nm}$ for $2 \mathrm{~min}$ at $37^{\circ} \mathrm{C}$ in $26 \mathrm{mmol}$ Tris- $\mathrm{HCl}$ buffer $\mathrm{I}^{-1}$, $\mathrm{pH} 8.0, \quad 0.825 \mathrm{mmol}$ 1,2-diacylglyceride $\mathrm{I}^{-1}, 1.5 \mathrm{mmol}$ sodium $\mathrm{N}$-ethyl-N-(2-hydroxy-3-sulphopropyl)-m-toluidine $\mathrm{I}^{-1}, 0.5 \mathrm{mmol}$ ATP $\mathrm{I}^{-1}, 4.0 \mathrm{mmol}$ cholic acid $\mathrm{I}^{-1}, 9.0 \mathrm{mmol}$ deoxycholate $\mathrm{I}^{-1}, 1.5 \mathrm{mmol}$ 4-aminoantipirine $\mathrm{I}^{-1}$ and $0.5 \mathrm{mg}$ sodium azide $\mathrm{ml}^{-1}$, in the presence of $30000 \mathrm{U} \mathrm{CO}^{-}$ lipase $\mathrm{I}^{-1}$, (1) $650 \cup$ monoacylglyceride lipase $\mathrm{I}^{-1}$, (2) $1000 \cup$ glycerol kinase $\mathrm{I}^{-1}$; (3) $30000 \mathrm{U}$ glycerol-3phosphate oxidase $\mathrm{I}^{-1}$ and (4) $1000 \mathrm{U}$ peroxidase $\mathrm{I}^{-1}$, using $240 \cup$ lipase solution $\mathrm{I}^{-1}$ as standard (Imamura et al., 1989).
An enzymatic unit for lipase is defined as the quantity of enzyme that catalyses the production of $1 \mu \mathrm{mol}$ fatty acid $\min ^{-1}$.

Lipase
1,2-Diacylglyceride $\rightarrow$ 2-monoacylglyceride + fatty acid

(1) 2-Monoacylglyceride $\rightarrow$ glycerol + fatty acid

(2) Glycerol + ATP $\rightarrow$ glycerol-3-phosphate + ADP

(3) Glycerol-3-phosphate $+\mathrm{O}_{2} \rightarrow$ dihydroxyacetone phosphate $+\mathrm{H}_{2} \mathrm{O}_{2}$

(4) $\mathrm{H}_{2} \mathrm{O}_{2}+4$-aminoantipyrine + sodium $\mathrm{N}$-ethyl- $\mathrm{N}$-(2hydroxy-3-sulphopropyl)-m-toluidine $\rightarrow$ quinone diimine dye $+4 \mathrm{H}_{2} \mathrm{O}$

\section{Determination of total proteins}

Total protein concentrations were determined in enzymatic extract supernatants using the method described by Lowry et al. (1951).

\section{Experimental design and statistical analysis}

Enzymatic activity was expressed as enzymatic units and specific activity. Enzymatic units were expressed in units per COC, denuded oocyte or cumulus. Determination of total proteins in enzymatic extracts enabled a comparison of the enzymatic activity between denuded oocytes and cumulus cells expressed in $U$ per $\mu$ g protein (specific activity). Data were expressed as means \pm SEM. Intra-assay and interassay variability were estimated according to Rodbard (1974) and expressed as coefficients of variation.

The enzymatic activity of each enzyme in COCs matured in vitro was determined by comparing immature and matured COCs using the Student's $t$ test. Activities in denuded oocytes and cumulus cells arising from immature and matured COCs were compared in a $2 \times 2$ factorial design to evaluate the enzymatic activity contribution by either type of COC cell.

Statistical analyses of meiotic maturation rates were made by chi-squared analysis.

A $P$ value $<0.05$ was considered significant.

\section{Results}

In samples used to evaluate meiotic maturation, the percentage of in vitro maturation was $80-85 \%$.

Phosphofructokinase activity expressed in enzymatic units remained constant in COCs during in vitro maturation (immature: $(1.21 \pm 0.17) \times 10^{-4}$, matured: $(1.20 \pm 0.13) \times$ $10^{-4}$, in contrast to the decrease observed in specific activity (immature: $(1.54 \pm 0.21) \times 10^{-4}$, matured: $(0.44 \pm 0.05) \times$ $10^{-4} ; P<0.05$ ) ( $n=10$ for each value). Enzymatic units remained constant in the oocyte and in the cumulus during in vitro maturation; the cumulus reached on average 102 times more enzymatic units than the oocyte $(P<0.05)$. Specific activity increased in the oocyte $(P<0.05)$ and diminished in cumulus cells during in vitro maturation 



Fig. 1. (a) Phosphofructokinase (PFK) activity in ( $\square$ ) denuded oocytes and ( $\square$ ) cumulus cells from immature and in vitro matured cumulus-oocyte complexes (COCs). Activity is measured (a) in units per denuded oocyte or cumulus and (b) as specific activity (units $\mu \mathrm{g}^{-1}$ protein). Values are means \pm SEMs of ten replicates. Within each part of the figure: abbars with different superscripts are significantly different $(P<0.05)$; ${ }^{c d}$ bars with different superscripts are significantly different; *significantly different from PFK activity of corresponding denuded oocyte $(P<0.05)$.
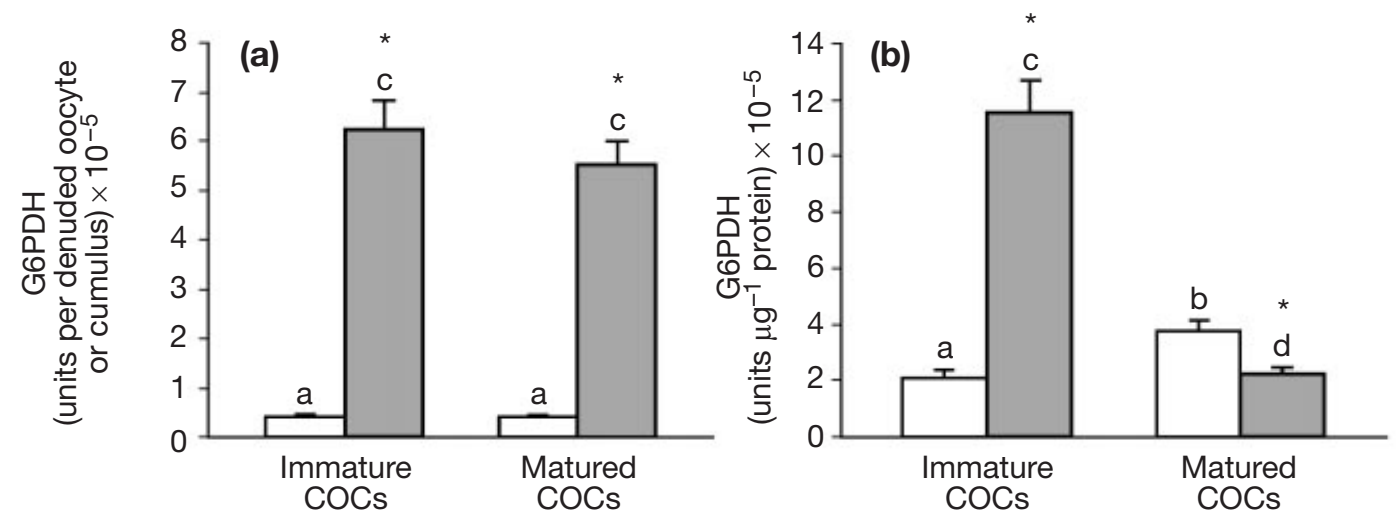

Fig. 2. (a) Glucose-6-phosphate dehydrogenase (G6PDH) activity in ( $\square$ ) denuded oocytes and ( $\square$ ) cumulus cells from immature and in vitro matured cumulus-oocyte complexes (COCs). Activity is measured (a) in units per denuded oocyte or cumulus and (b) as specific activity (units $\mu \mathrm{g}^{-1}$ protein). Values are means \pm SEMs of 10-11 replicates. Within each part of the figure: abbars with different superscripts are significantly different $(P<0.05)$; cdbars with different superscripts are significantly different; *significantly different from G6PDH activity of corresponding denuded oocyte $(P<0.05)$.

$(P<0.05)$; however, activity was always higher in cumulus cells $(P<0.05$; Fig. 1$)$.

G6PDH activity expressed in units did not change in COCs during in vitro maturation (immature: $(6.34 \pm 0.74) \times 10^{-5}$, matured: $(6.64 \pm 0.61) \times 10^{-5}$, in contrast to the decrease observed in specific activity (immature: $(7.78 \pm 0.88) \times$ $10^{-5}$, matured: $\left.(2.68 \pm 0.24) \times 10^{-5} ; P<0.05\right)(n=14$ for each value). Enzymatic units remained constant in the oocyte and cumulus during in vitro maturation; the cumulus reached on average 14 times more enzymatic units than the oocyte $(P<0.05)$. Specific activity increased in the oocyte $(P<0.05)$ and diminished in cumulus cells $(P<0.05$; Fig. 2$)$.

Lipase units (immature: $(3.13 \pm 0.24) \times 10^{-5}$, matured: $\left.(2.00 \pm 0.13) \times 10^{-5}\right)$ and its specific activity (immature: $(4.06 \pm 0.30) \times 10^{-5}$, matured: $\left.(0.88 \pm 0.06) \times 10^{-5}\right)$ de- creased significantly in COCs during in vitro maturation $(P<0.05)$ ( $n=10$ for each value). Enzymatic units diminished significantly in the cumulus during in vitro maturation $(P<0.05)$, but remained constant in the oocyte. Immature cumulus enzymatic units were twofold higher than in the oocyte $(P<0.05)$ and those of matured cumulus decreased to similar values. Specific activity increased in the oocyte $(P<0.05)$ and decreased in cumulus cells $(P<0.05)$; however, activity was always higher in the oocyte during maturation ( $P<0.05$; Fig. 3 ).

Repeatability of data for enzymatic units and specific activity were similar in COCs, denuded oocytes and cumulus cells for each enzyme; phosphofructokinase: intra-assay coefficient of variation $=25-40 \%$ and interassay coefficient of variation $=0-30 \%$; G6PDH: intra-assay coefficient of 

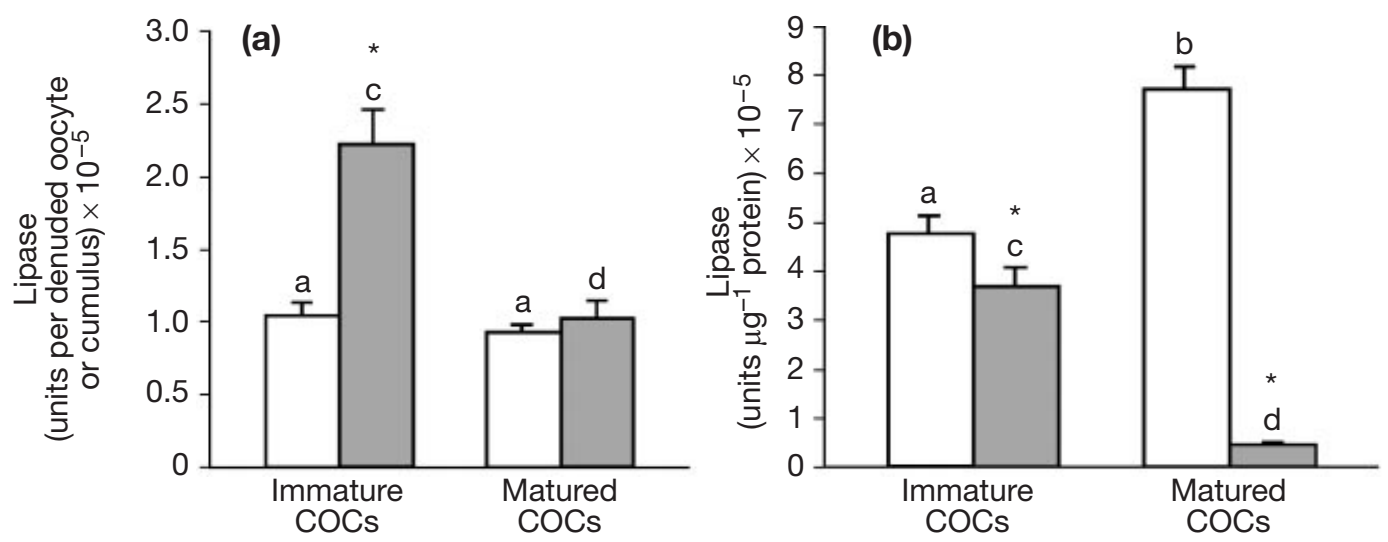

Fig. 3. (a) Lipase activity in ( $\square$ ) denuded oocytes and ( $\square$ ) cumulus cells from immature and in vitro matured cumulus-oocyte complexes (COCs). Activity is measured (a) in units per denuded oocyte or cumulus and (b) as specific activity (units $\mu \mathrm{g}^{-1}$ protein). Values are means \pm SEMs of 10 replicates. Within each part of the figure: abbars with different superscripts are significantly different $(P<0.05)$; ${ }^{c d}$ bars with different superscripts are significantly different; *significantly different from lipase activity of corresponding denuded oocyte $(P<0.05)$.
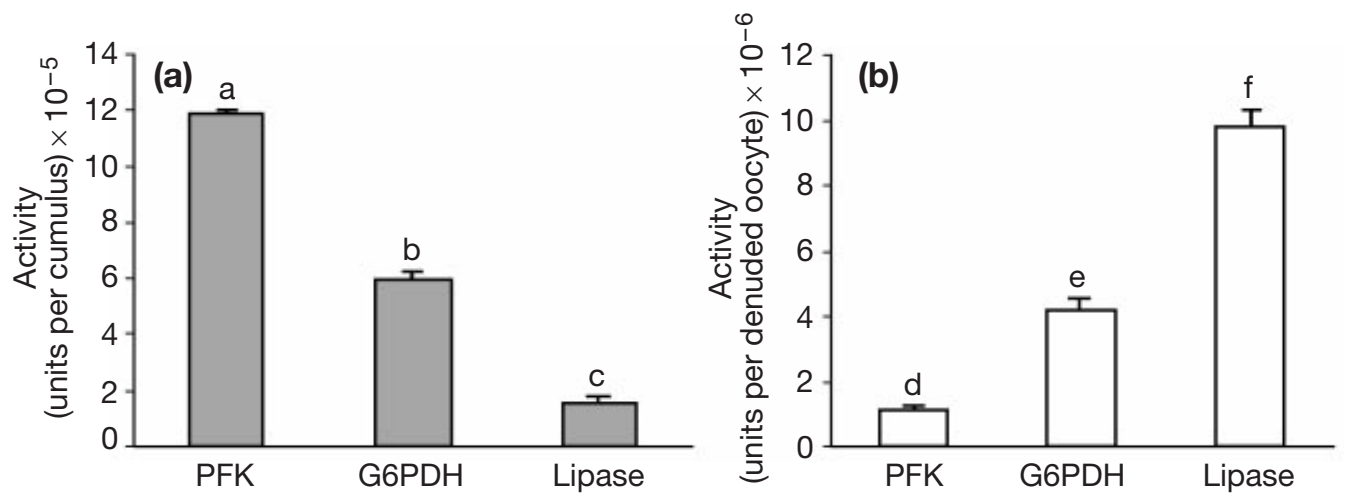

Fig. 4. Comparison between phosphofructokinase (PFK), glucose-6-phosphate dehydrogenase (G6PDH) and lipase units in (a) cumulus and (b) denuded oocytes. Values are the average enzymatic units of immature and matured cumulus and denuded oocytes. Values are means \pm SEMs of 20-22 replicates. abcBars with different superscripts are significantly different $(P<0.05)$. defBars with different superscripts are significantly different $(P<0.05)$.

variation $=24-40 \%$ and interassay coefficient of variation $=0-23 \%$; lipase: intra-assay coefficient of variation $=$ $10-40 \%$ and interassay coefficient of variation $=0-25 \%$.

For each enzyme studied, the average value was calculated between immature and matured cumulus enzymatic units and between matured cumulus and denuded oocyte enzymatic units. Average values for the three enzymes studied were then compared to establish the relationship between enzymatic activities in each type of cell. In cumulus cells, phosphofructokinase was the most abundant enzyme followed by G6PDH and then lipase $(P<0.05)$, whereas in the denuded oocyte this order was reversed $(P<0.05 ;$ Fig. 4). The comparison was not expressed for specific activities because the relationship is equivalent to the relationship expressed as enzymatic units.

\section{Discussion}

The activities of phosphofructokinase and G6PDH expressed as units per COC did not change during maturation, as activity of both denuded oocytes and cumulus cells did not vary during maturation. The amount of protein present in bovine cumulus cells increases gradually during the $24 \mathrm{~h}$ of in vitro maturation, possibly because of the increase in the number of cumulus cells (Wu et al., 1996; Cetica et al., 2001). However, a slight but significant decrease in total protein concentration in extracts of denuded bovine oocytes was reported by Cetica et al. (2001), and a decrease in the rate of protein synthesis by Wu et al. (1996) and Gandolfi (1998). These findings explain the decrease in cumulus cells and the increase in denuded oocyte specific 
activity recorded for both enzymes during maturation. Therefore, it may be inferred that the enzymatic activity of cumulus cells would decrease gradually when cumulus expansion occurs during maturation. The enzymes studied would not be involved in the detected loss of oocyte proteins, indicating that the gamete maintains its enzymatic activity even when dissociated from cumulus cells during maturation.

The low phosphofructokinase activity observed in the denuded oocyte indicates a minor participation of the glycolytic pathway in the bovine gamete, which is in agreement with the reduced amount of phosphofructokinase transcript detected in human oocytes (El Mouatassim et al., 1999b). Although enzyme activity was low in the oocyte, it was still detectable, which indicates that the difficulty in using glucose could depend not only on low enzyme concentration but also on regulatory allosteric mechanisms, or on the reported decrease in glucose transporter GLUT-1 (Lequarre et al., 1997). On average, bovine cumulus cells displayed 102 times more phosphofructokinase units than did the oocyte and specific activity remained very high in comparison with that of the denuded oocyte during maturation, indicating that this regulatory glycolytic pathway enzyme plays a key role in the metabolism of these cells. These results support the contention that cumulus cells could catabolize glucose by the glycolytic pathway, supplying pyruvate or lactate to the oocyte as oxidative substrates (Cetica et al., 1999b).

Rieger and Loskutoff (1994) suggested that the activities of the glycolytic and pentose phosphate pathway are low in the bovine oocyte during maturation because of limited glucose uptake by the gamete. However, the results of the present study indicate that G6PDH activities (units) in the cumulus are on average 14 times greater than in the denuded oocyte, a much smaller difference than for phosphofructokinase. Besides, G6PDH activity in the denuded oocyte was on average almost fourfold higher than the activity observed for phosphofructokinase, which possibly denotes a greater relative involvement of the pentose phosphate pathway than of the key glycolysis enzyme in the gamete. In support of this finding, rat oocytes also have higher G6PDH activity than phosphofructokinase activity (Tsutsumi et al., 1992). These findings are in agreement with reports that glucose uptake by bovine oocytes during in vitro maturation are mainly metabolized by the pentose phosphate pathway (Javed and Wright, 1991; Krisher and Bavister, 1998). A decrease in maturation was observed in mouse COCs when using inhibitors of NADP-dependent enzymes acting by the pentose phosphate pathway, implying that glucose metabolism by this pathway is essential for meiotic induction (Downs et al., 1998; Downs and Utecht, 1999). G6PDH in cumulus cells could provide NADPH for the synthesis of structural lipids in these cells with high replication activity or to transfer NADPH to the oocyte for its own reductive pathways. In the oocyte, NADPH released by cumulus cells and NADPH produced by the high G6PDH activity would be necessary for the synthesis of lipids and the regeneration of reduced glutathione. Indeed, glutathione synthesis occurs during bovine oocyte matura- tion and may play a leading role in sperm nuclear decondensation during fertilization (Sutovsky and Schatten, 1997).

Differences in phosphofructokinase and G6PDH activities during in vitro maturation of rodent (Tsutsumi et al., 1992) versus bovine oocytes may be observed, indicating that the gamete displays a differential metabolism among species and components of maturation media should be adapted to the species under study. In a comparative analysis, differences have also been observed between metabolic enzyme activities in mouse and human oocytes (Chi et al., 1988).

Among the enzymes studied, there was a decrease in enzymatic activity expressed as units per COC only for lipase as a result of in vitro maturation and, therefore, an even more marked decrease was observed when expressed as specific activity. The decrease in activity of lipase in cumulus cells seems to be responsible for the decrease in lipase activity observed in COCs, indicating that the lipolytic function of cumulus cells decreases rapidly when cumulus cells are separated from the oocyte. During the growth stage and at the start of bovine oocyte maturation, cumulus cells may supply fatty acids to the oocyte as a result of lipase activity, as described in follicular cells of non-mammalian species (Benson et al., 1975; Van Antwerpen et al., 1998). Kim et al. (2001) suggested that serum lipids and fatty acids may be incorporated into the oocyte cytoplasm during in vitro maturation. Specific activity of lipase in both immature oocytes and oocytes that were matured in vitro was higher than in cumulus cells, in contrast to observations on key enzymes of glucose catabolism, indicating a greater involvement of the enzyme in the gamete. The availability of lipid reserves and of lipase activity would enable the oocyte to use lipids as oxidative substrates after it is separated from cumulus cells during maturation. These data appear to be linked to the decrease in triglyceride content recorded during in vitro maturation of bovine oocytes (Ferguson and Leese, 1999; Kim et al., 2001). In humans and cows, palmitic acid is the most abundant fatty acid in the oocyte and its main function is to provide energy (Matorras et al., 1998; Kim et al., 2001).

In conclusion, the findings from the present study indicate that the metabolism of cumulus cells is adapted to control the flow of metabolites toward the oocyte. On dissociation from cumulus cells, the oocyte appears to maintain the necessary enzymatic activities for its metabolic requirements during maturation. The high activity of phosphofructokinase in cumulus cells could indicate a major participation of the glycolytic pathway to supply substrates to the oocyte. The greater relative activity of G6PDH in the oocyte indicates that glucose could be directed mainly toward the pentose phosphate pathway for NADPH production. In turn, the marked lipolytic activity of the oocyte indicates active lipid catabolism during maturation.

This work was supported by a grant from the University of Buenos Aires. The authors thank Japanese International Cooperation Agency (JICA) for technology transfer and equipment, Deltacar, La Foresta and El Rioplatense abottoirs for ovaries, Astra Laboratories 
for ultra-pure water, S. Paganitts Llanes for his technical assistance and L. Marangunich for her statistical suggestions.

\section{References}

Barnett D and Bavister B (1996) What is the relationship between the metabolism of preimplantation embryos and their developmental competence? Molecular Reproduction and Development 43 105-133

Benson J, Bensadoun A and Cohen D (1975) Lipoprotein lipase of ovarian follicles in the domestic chicken (Gallus domesticus) Proceedings of the Society of Experimental Biology and Medicine 148 347-350

Buccione R, Schoeder A and Eppig J (1990) Interactions between somatic cells and germ cells throughout mammalian oogenesis Biology of Reproduction 43 543-547

Cetica P, Dalvit G and Beconi M (1999a) Study of evaluation criteria used for in vitro bovine oocyte selection and maturation Biocel/ 23 125-133

Cetica P, Pintos L, Dalvit G and Beconi M (1999b) Effect of lactate dehydrogenase activity and isoenzyme localization in bovine oocytes and utilization of oxidative substrates on in vitro maturation Theriogenology $\mathbf{5 1}$ 541-550

Cetica P, Pintos L, Dalvit G and Beconi M (2001) Antioxidant enzyme activity and oxidative stress in bovine oocyte in vitro maturation IUBMB Life 51 57-64

Chi M, Manchester J, Yang V, Curato A, Strickler R and Lowry O (1988) Contrast in levels of metabolic enzymes in human and mouse ova Biology of Reproduction 39 295-307

Clarenburg R (1992a) Carbohydrate metabolism. In Physiological Chemistry of Domestic Animals pp 239-291 Ed. R Reinhardt. Mosby Year Book Inc., Saint Louis

Clarenburg R (1992b) Lipid metabolism. In Physiological Chemistry of Domestic Animals pp 292-333 Ed. R Reinhardt. Mosby Year Book Inc., Saint Louis

de Loos F, Kastrop P, van Maurik P, van Beneden T and Kruip T (1991) Heterologous cell contacts and metabolic coupling in bovine cumulus oocyte complexes Molecular Reproduction and Development 28 255-259

Downs S and Utecht A (1999) Metabolism of radiolabeled glucose by mouse oocytes and oocyte-cumulus cell complexes Biology of Reproduction 60 1446-1452

Downs S, Humpherson P and Leese H (1998) Meiotic induction in cumulus cell-enclosed mouse oocytes: involvement of the pentose phosphate pathway Biology of Reproduction 58 1084-1094

El Mouatassim S, Hazout A, Bellec V and Ménézo Y (1999) Glucose metabolism during the final oocyte maturation: genetic expression of hexoquinase, glucose phosphate isomerase and phosphofructokinase Zygote 7 45-50

Ferguson E and Leese $\mathbf{H}$ (1999) Triglyceride content of bovine oocytes and early embryos Journal of Reproduction and Fertility 116 373-378

Gandolfi F (1998) Embryo development as a function of oocyte competence. In Gametes: Development and Function pp 337-353 Eds A Lauria, F Gandolfi, G Enne and L Gianaroli. Tabloid SRL, Rome

Gardner D (1998) Changes in requirements and utilization of nutrients during mammalian preimplantation embryo development and their significance in embryo culture Theriogenology 49 83-102

Imamura S, Hirayama T, Arai T, Takao K and Misaki H (1989) An enzymatic method using 1,2-diglyceride for pancreatic lipase test in serum Clinical Chemistry (Abstract) $\mathbf{3 5} 1126$

Javed M and Wright R, Jr (1991) Determination of pentose phosphate and Embden-Meyerhof pathway activities in bovine embryos Theriogenology 35 1029-1037

Khoo J and Steinberg D (1981) Hormone-sensitive lipase from chicken adipose tissue including the separation and purification of monoglyceride lipase Methods in Enzymology 71 627-646

Kim J, Kinoshita M, Ohnishi M and Fukui Y (2001) Lipid and fatty acid analysis of fresh and frozen-thawed immature and in vitro matured bovine oocyte Reproduction 122 131-138

Kornberg A and Horecker B (1955) Glucose-6-phosphate dehydrogenase Methods in Enzymology $1323-327$

Kotlarz D and Buc H (1982) Phosphofructokinases from Escherichia coli. Methods in Enzymology 90 60-70
Krisher R and Bavister B (1998) Responses of oocytes and embryos to the culture environment Theriogenology 49 103-114

Kruip T, Cran D, Beneden T and Dieleman S (1983) Structural changes in bovine oocytes during final maturation in vivo. Gamete Research $829-47$

Laurincik J, Kroslak P, Hyttel P, Pivko J and Sirotkin A (1992) Bovine cumulus expansion and corona-oocyte disconnection during culture in vitro. Reproduction, Nutrition and Development 32 151-161

Leese $\mathbf{H}$ and Barton A (1984) Pyruvate and glucose uptake by mouse ova and preimplantational embryos Journal of Reproduction and Fertility 72 9-13

Lequarre A, Grisart B, Moreau B, Schuurbiers N, Massip A and Dessy F (1997) Glucose metabolism during preimplantation development: analysis of gene expression in single oocytes and embryos Molecular Reproduction and Development 48 216-226

Lohr G and Waller H (1974) Glucose-6-phosphate dehydrogenase. In Methods in Enzymatic Analysis pp 636-643 Ed. H Bergmeyer. Academic Press, New York

Lowry O, Rosebrough N, Farr A and Randall R (1951) Protein measurement with the Folin phenol reagent The Journal of Biological Chemistry 193 265-275

Mangia F and Epstein C (1975) Biochemical studies of growing mouse oocytes: preparation of oocytes and analysis of glucose-6-phosphate dehydrogenase and lactate dehydrogenase activities Developmental Biology 45 211-220

Matorras R, Ruiz J, Mendoza R, Ruiz N, Sanjurjo P and Rodriguez Escudero F (1998) Fatty acid composition of fertilization-failed human oocytes Human Reproduction 13 2227-2230

Rieger D and Loskutoff N (1994) Changes in the metabolism of glucose, pyruvate, glutamine and glycine during maturation of cattle oocytes Journal of Reproduction and Fertility $100257-262$

Rodbard D (1974) Statistical quality control and routine data processing for radioimmunoassays and immunoradiometric assays Clinical Chemistry $201255-1270$

Schirmer T and Evans P (1990) Structural basis of the allosteric behaviour of phosphofructokinase Nature 343 140-145

Susko-Parrish J, Aktas H and Leibfried-Rutledge M (1992) The effect of energy substrates during maturation on the fertilization and development of bovine oocytes Theriogenology (Abstract) 37305

Sutovsky P and Schatten G (1997) Depletion of glutathione during bovine oocyte maturation reversibly blocks the decondensation of the male pronucleus and pronuclear apposition during fertilization Biology of Reproduction 56 1503-1512

Sutovsky P, Fléchon J, Fléchon B, Motlik J, Peynot N, Chesné P and Heyman Y (1993) Dynamic changes of gap junctions and cytoskeleton during in vitro culture of cattle oocyte cumulus complexes Biology of Reproduction 49 1277-1287

Tarkowski A (1966) An air-drying method for chromosome preparations from mouse eggs Cytogenetics 5 394-400

Tsutsumi O, Satoh K, Taketani Y and Takahiko K (1992) Determination of enzyme activities of energy metabolism in the maturing rat oocyte Molecular Reproduction and Development 33 333-337

Van Antwerpen R, Salvador K, Tolman K and Gentry C (1998) Uptake of lipids by developing oocytes of the hawkmoth Manduca sexta. The possible role of lipoprotein lipase Insect Biochemistry and Molecular Biology 28 399-408

Wood T (1986) Physiological functions of the pentose phosphate pathway Cell Biochemistry and Function 4 241-247

Wu B, Ignotz G, Currie W and Yang X (1996) Temporal distinctions in the synthesis and accumulation of proteins by oocytes and cumulus cells during maturation in vitro of bovine oocytes Molecular Reproduction and Development 45 560-565

Zuelke K and Brackett B (1992) Effects of luteinizing hormone on glucose metabolism in cumulus enclosed bovine oocytes matured in vitro. Endocrinology 131 2690-2696

Received 5 April 2002.

First decision 22 May 2002.

Revised manuscript received 22 July 2002.

Accepted 9 August 2002. 